Case Report

DOI: $10.15436 / 2381-1404.18 .1900$

\title{
Double Philadelphia Chromosome-Positive B Acute Lymphoblastic Leukemia
}

\author{
Honggang Cao, Jing Li, Tao Wu*, Dongfeng Mao, Cunbang Wang, Hai Bai
}

Department of Hematology, Lanzhou General Hospital, Lanzhou Command, Lanzhou, Gansu, China

*Corresponding author: Dr. Tao Wu, Department of Hematology, Lanzhou General Hospital, Lanzhou Command, 333 South Binhe Rd, Lanzhou, Gansu, 730050, China,Tel: +86-13919939297/ Fax:+86-931-2665486; E-mail: wutao2009@126.com

Citation: Wu, T., et al. Double Philadelphia Chromosome-Positive B Acute Lymphoblastic Leukemia. (2018) Int J Hematol Ther 4(1): 34- 35 .

\section{Introduction}

Philadelphia $(\mathrm{Ph})$ chromosome is the derivative chromosome 22 that results from reciprocal translocation $t(9 ; 22)$ (q34;q11). It has been found in about $95 \%$ of chronic myeloid leukemia (CML), less often presented in acute lymphocytic leukemia (ALL, about $25 \%$ in adult and $2-4 \%$ in pediatrics) and occasionally observed in acute myelogenous leukemia (AML) ${ }^{[1]}$. While double $\mathrm{Ph}$ chromosomes can be reported in some cases of CML during blastcrisis, it is rarely reported in ALL. We present a rare case of a lady with a diagnosis of double Ph-positive B-ALL who achieved a continuous complete response after treatment with a combination of conventional chemotherapy and tyrosine kinase inhibitor (TKI) as follows.

\section{Case Report}

A 53-year-old lady was admitted to our hospital with half a month history of fever, fatigue and dizziness. Physical examination revealed palpable sternal tenderness. Peripheral blood tests showed white cell count $95.39 \times 10^{9} / \mathrm{L}$, hemoglobin 100 $\mathrm{g} / \mathrm{L}$ and platelet $18 \times 10^{9} / \mathrm{L}$. Peripheral blood cell morphology showed: lymphoblasts 44\%, immature lymphocytes 50\%. Bone marrow cytology showed $98 \%$ blasts which were heterogeneous in size. Immunophenotype of the blast cells showed: CD10+, CD13+, CD19+, CD20+, CD22+, CD33+, CD34+. Chromosome analysis revealed a $47 \sim 50, \mathrm{XX},+5,+8, \mathrm{t}(9 ; 22)(\mathrm{q} 34 ; \mathrm{q} 11)$, $+\operatorname{der}(22) \mathrm{t}(9 ; 22)$ karyotype (Figure 1). In conclusion, her final diagnosis was B-ALL with double Ph chromosome. She was initially treated with conventional chemotherapy and regular intrathecal chemotherapy. As Ph chromosome was positive, imatinib was subsequently administered. She achieved a complete remission and had stayed in continuous remission for two months.
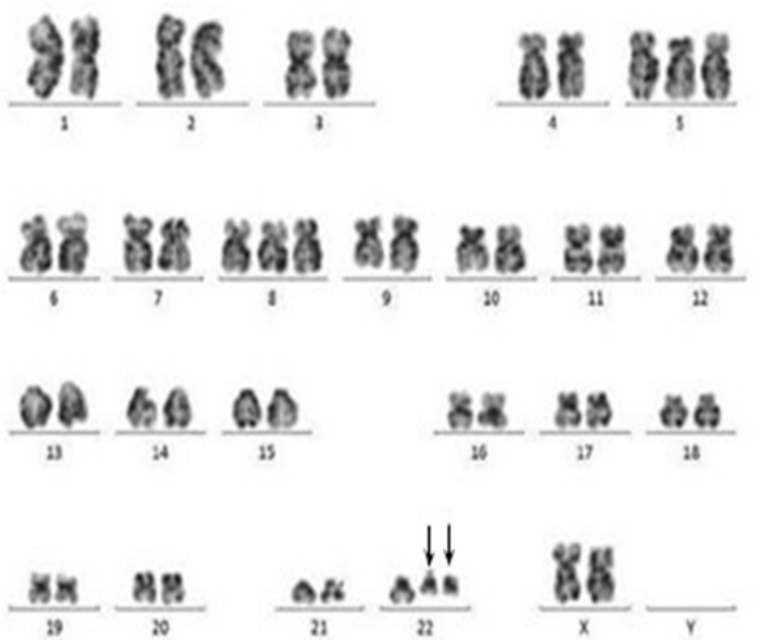

Figure 1: Karyotype of bone marrow showed $47 \sim 50, \mathrm{XX},+5,+8$, $\mathrm{t}(9 ; 22)(\mathrm{q} 34 ; \mathrm{q} 11), \operatorname{der}(22) \mathrm{t}(9 ; 22)$. There was presence of two truncated $\mathrm{Ph}$ chromosomes 22 (arrows).

\section{Discussion}

$\mathrm{Ph}$ chromosome positive ALL is associated with a highly aggressive disease, more resistant to chemotherapy ${ }^{[2]}$, and lower remission rate and shorter survival when compared with $\mathrm{Ph}$ chromosomenegative ${ }^{[3]}$. Affected patients usually present with signs and symptoms related to bone marrow failure. The current standard therapy for $\mathrm{Ph}$ chromosome-positive B-ALL ischemotherapy in addition to TKI, and allogeneic stem cell transplantation after first remission is believed to be the treatment of choice in adult $\mathrm{Ph}$ chromosome positive ALL, when possible ${ }^{[4]}$. 
Double Ph chromosome-positive B-ALL is reported in several case reports worldwide ${ }^{[1,5-7]}$. The possible mechanism of double $\mathrm{Ph}$ chromosome is considered to be the result of non-disjunction occurring during mitosis ${ }^{[1]}$. However, the clinical significance of double Ph chromosomes in ALL has not been known. It is reported that double $\mathrm{Ph}$ chromosome-positive ALL patients have lower probability of complete hematological response, shorter time to progression and inferior overall survival when compared with single $\mathrm{Ph}$ chromosome ${ }^{[8]}$.

We describe here the rare case of an elderly female patient with double $\mathrm{Ph}$ chromosome-positive B-ALL who stayed in continuous complete remission for two months after initial therapy. As a whole, the case is consistent with the literature reports, but long-term efficacy needs to be further observed. Therefore, a further large number of cases are needed to probe into the clinical significance of double $\mathrm{Ph}$ chromosome in B-ALL.

Acknowledgements: This work was sponsored by the grant from the natural science foundation of Gansu Province (145RJZA151).

Authors' declaration: All authors read and approved the final manuscript. All authors declare no conflict of interest.

\section{References}

1. Tang, Y.L., Raja Sabudin, R.Z., Leong, C.F., et al. Double Philadelphia chromosome positive B acute lymphoblastic leukemia in an elderly patient. (2015) Malays J Pathol 37(3): 275-279.

PubMed |CrossRef| Others

2. Rowe, J.M., Buck, G., Burnett, A.K., et al. Induction therapy for adults with acute lymphoblastic leukemia: results of more than 1500 patients from the international ALL trial: MRC UKALL XII/ECOG E2993. (2005) Blood 106(12): 3760-3767. PubMed | CrossRef | Others

3. Secker-Walker, L.M., Craig, J.M., Hawkins, J.M., et al. Philadelphia positive acute lymphoblastic leukemia in adults: age distribution, BCR break - point and prognostic significance. (1991) Leukemia 5(3): 196-199.

PubMed |CrossRef| Others

4. Ottmann, O.G., Wassmann, B. Treatment of Philadelphia chromosome-positive acute lymphoblastic leukemia. (2005) ASH Education Book 2005(1): 118-122.

PubMed |CrossRef|Others

5. Vaz de Campos, M.G., Chauffaille, M.L.L.F., Rodrigues, C.A., et al. A rare case of Acute Lymphocytic Leukemia (ALL) presenting with double Philadelphia chromosome - relapse or secondary leukemia? (2003) Genet Mol Biol 26(3): 249-251.

PubMed |CrossRef | Others

6. Takasaki, H., Kanamori, H., Takabayashi, M., et al. Double Philadelphia chromosomes positive acute lymphocytic leukemia. (2003) Leuk Lymphoma 44(4): 735-736.

PubMed | CrossRef | Others

7. Yahata, N., Tauchi, T., Kimura, Y., et al. Double Philadelphia chromosomes in acute lymphocytic leukemia. (2000) Cancer Genet Cytogenet 121(1): 101-102. PubMed | CrossRef | Others

8. Wassmann, B., Pfeifer, H., Scheuring, U.J., et al. Early prediction of response in patients with relapsed or refractory Philadelphia chromosome-positive acute lymphoblastic leukemia (Ph+ALL) treated with imatinib. (2004) Blood 103(4): 1495-1498.

PubMed | CrossRef | Others

Submit your manuscript to Ommega Publishers and we will help you at every step:

- We accept pre-submission inquiries

- Our selector tool helps you to find the most relevant journal

- We provide round the clock customer support

- Convenient online submission

- Thorough peer review

- Inclusion in all major indexing services

- Maximum visibility for your research

Submit your manuscript at

ommega Publishers

https://www.ommegaonline.org/submit-manuscript 